\title{
Analysis of Formation of Students 'Character Through Rattan Traditional Games at Periuk 2 Private Vocational School, Tangerang City
}

\author{
Ahmad Muchlisin Natas Pasaribu ${ }^{1}$ \\ $\left\{\right.$ Ahmadmuchlisinnatas@gmail.com ${ }^{1}$ \} \\ Department of Primary Teacher Education, Muhammadiyah University of Tangerang, Tangerang, \\ Banten, Indonesia ${ }^{1}$
}

\begin{abstract}
Many traditional games that contain character values. But nowadays traditional games are increasingly being replaced by digital games. The focus in this study is the analysis of character values contained in traditional mouse rat games with the aim of describing character values in traditional mouse rat games. This study uses qualitative research, where research is based on the philosophy of logical postpositivism, used to examine the condition of natural objects. Data collection methods use observation, documentation and interviews. Data validity techniques using triangulation. Data analysis techniques use data collection, data selection, presenting data and drawing conclusions. The results of the study show that there are several character values integrated in traditional mouse cat games, namely religious values, curiosity values, honest values, values of responsibility, value of hard work, value of social care, value of love for the homeland, value of democracy and value of discipline.
\end{abstract}

Keywords: Traditional cat mouse game, character value.

\section{Introduction}

The education process is basically the right of every human being, as stated in the National Education System Law Number 20 of 2003 Chapter 1 article 1 (1), namely: Education is a conscious and planned effort to realize the learning atmosphere and learning process so that students actively develop their potential himself to have religious spiritual strength, selfcontrol, personality, ingenuity, noble character, and the skills needed by him, the people of the nation and the State. Government regulations on the national education system at this time education applied in schools, especially primary schools, emphasizes character building. The character in question is a character that was formulated by the Ministry of Education and Culture in 2011 is expected to be able to shape the character of students themselves, maybe starting from the elementary school level. Activities that can develop the ability of character building through traditional games of mouse class II in SDN Periuk II are optimal. Second grade students of SDN Periuk II all class II students already knew the traditional game of mouse cats so that in learning using variations of mouse cat games students were very enthusiastic about the games and learning that would be discussed. One of the causes of students 'enthusiasm for the traditional game of mouse cats is an activity that develops students' character abilities in the game so that the child's body is often easy to carry out 
learning that uses traditional variations of cat mouse games, so that the child has been stimulated in developing the ability to form traditional mouse rat games.

Character is a person's nature in responding to a situation morally, which is manifested in real action through good behavior, honesty, responsibility, respect for others, and other character values. Poerwadarminta explained that "character is defined as character, character, psychological characteristics, character or character that distinguishes one person from another, Lusiana (2012: 46). Based on this expression, it states that the character is the behavior or manner of an ethical person from each individual who is different. According to Mulyasa (2014: 4). Based on this expression shows that character means the behavior characteristics of a person that distinguishes between one individual and another.

Whereas according to Wynne (2014: 3) character is "to mark" marks and focuses on how to apply the values of goodness in real actions or everyday behavior. Based on this expression, it shows that character means applying values of kindness and focusing on real actions or everyday behavior. Furthermore Sani and Kadri (2016: 8) stated that character is a good thing, for example related to honesty, tolerance, hard work, fairness and trustworthiness. But without strong faith in Allah SWT. Based on these expressions, it states that character is the way each individual behaves in accordance with the tolerance that exists in each individual. As for Gunawan, (2014: 2) character is a characteristic possessed by an object or individual (human). These characteristics are genuine, and are rooted in the personality of the object or individual and are a driving force for how a person acts, behaves, speaks, and responds. Based on this expression states that character is a special characteristic that is owned by each individual with each difference. From some of the above expert understandings, it can be concluded that the characters are identical with morals so that the characters are universal human behavior values which cover all human activities, both in relation to God, self, fellow human beings, and the environment manifested in the mind, attitude, feelings, words, and deeds based on the norms of religion, law, karmic order, culture and customs.

Psychologically and sociologically in humans there are things related to the formation of characters. According to Majid and Andayani (2013: 17) revealed that "the most important element in character building is the mind because the mind in which there are all programs formed from his life experience, is a pioneer of everything. Based on this expression shows that character formation there are several important things in it such as the mind and attitude of a person who is part of the character, even the attitude is considered as a reflection of the character of the person. Furthermore Fatchul (2011: 167) states that there are five elements that shape human character, namely Attitude, a reflection of one's own character, attitude also becomes a powerful tool for positive or negative actions because attitude is an action on the expression of a person's soul. Emotion, is a dynamic symptom in a situation that is felt by humans, in general there are four emotions that can be seen from the facial expressions that we often encounter namely fear, anger, sadness, and pleasure. Trust, is a form of knowledge, so that what we know makes us make choices because we believe what we take. Habit and will, is an aspect of behavior that is permanent in a person and is done repeatedly. Whereas the will is the action of one's efforts to achieve goals. Self-concept, is an introduction to oneself or self-esteem, this is very important in shaping character because someone will be easily harassed by others when we are weak in ourselves. Based on this expression shows that psychologically and sociologically humans have several elements related to the formation of character. Furthermore, Helmawati (2017: 20) states that the character building of a person who has the most influence is the environment both family environment, school environment and community environment. From some expert opinions above it can be concluded that 
character formation is formed through various learning processes obtained from various places such as home, school and also the neighborhood.

Speaking of students' character is a whole there are behaviors and abilities that exist in students as a result of the carrying out of the social environment so as to determine the pattern of activity in achieving his goals. According to Taufik (2013: 231) elementary students are in concrete operational development. Children think on the basis of real / concrete experience, have not been able to think like imagining how photosynthesis or the osmosis process occurs. However, the ability to add, subtract, sort and classify has developed with simple multiplication and division. Women for a little abstract thinking always have to be preceded by concrete experience. Primary school age children are still in dire need of concrete objects to help develop their intellectual abilities. According to Nasution (2011: 124) the primary school age as a late childhood that lasted from the age of six years to approximately eleven or twelve years. This age is marked by the start of children entering elementary school, and the start of a new history that will change attitudes and behavior. From the explanation of the experts above, it can be concluded that the characteristics of students through traditional game learning are basically formed through a long learning process in the education world.

Children must be directed when playing, so they are not just playing but also learning. Thus we must package children's learning with game methods so that children feel happy and excited when learning. According to Soepandi, Skar and Kawan-kawan (1986: 15), the game is an act to entertain the heart, whether it is using the tool or not using the tool. Whereas what is meant traditionally is all that is said or passed down from generation to generation from parents or ancestors. So traditional games are all good deeds using tools or not, which are inherited from generation to generation, as a means of entertainment or to please the heart (Misbach, 2006: 6). Traditional games are nothing but activities governed by a game regulation which is inherited from previous generations by humans (children) with the aim of getting fun (Misbach, 2006: 5). From the understanding of traditional learning methods and games above, it can be concluded that the traditional game method is an operational procedure that is used to convey the subject matter to students, by packing the learning process with game activities that are born from a particular cultural heritage, so that the learning objectives can be achieved well .

The mouse cat game is this game called the mouse cat because the players are likened to cats and mice. Cats are rat eaters, so here the cat will try to chase mice. This game is played outdoors or home page. Actually this game can be done by children with an unlimited duration of time, until they feel tired. However, if we are included in the learning process, to be more effective and avoid children from getting bored the game can be done with a duration of about 15-30 minutes. This game is usually done by children aged around 6 to 12 years. There are no special equipment prepared for this game. Before the game starts, first, who is the rat, can it be hompipah. If you get one person as a cat, then the rest becomes a rat. The rats formed a circle by holding hands tightly, one mouse was in a circle, and the cat was in a circle, and I was outside the circle. Cats must try to catch mice by breaking through the circle of couplings with mouse rescuers trying to protect mice. If the cat feels unable to break through the circle at one point because it is too strong, the cat can choose another place. If the cat manages to break into the circle, the mice are given the opportunity to save themselves by being given a way out. If the cat manages to get out of the circle, the mouse is given the opportunity to enter the circle. When the mouse is outside or inside the circle keep trying to stay away from the cat. The mouse that successfully touched the cat was declared dead and he acted as a rat. The one who plays the role of a mouse in a circle can alternate. If the cat manages to catch a mouse, the participant who becomes the rat and his team get a sentence. 
From the above explanation it can be concluded that traditional games that are quite diverse need to be explored and developed because they contain values such as honesty, sportsmanship, persistence, and mutual cooperation. With traditional games, children can practice concentration, knowledge, attitudes, skills and dexterity that are purely carried out by the human brain and body. In addition, traditional games can also develop aspects of moral development, religious values, social, language and motor functions.

\section{Research methods}

The research uses descriptive method, which is to describe in depth with what it is objectively according to the data collected. The data comes from observations, interviews, field notes, photographs and other official documents.

\section{Research result}

Based on the results of observations, interviews and documentation that the researchers conducted in the field, the traditional game of mouse cats in the primary school of Periuk 2 in Tangerang City in grade 2 went well. Even the sports that are in this school are in accordance with the predetermined lesson schedule. exercise time is carried out according to the schedule. The student is given a sanction, in the form of a warning. If there is still something like that then the sanctions continue. If anyone quarrels I will separate, then I bring students who make the problem in front, then there will be no more noise.

Adapted to the indicators in the book, THEME, if you already know the indikoator, that's why the game that approaches the indicator, for example, students are asked to run, I apply it to a game that has a run like a mouse cat. It is more important for traditional games because besides giving knowledge to children that we have traditional games that we have to preserve. It has a very big influence because in traditional games we can teach about gross motor skills, which are about agility, activity, speed and providing creativity to children, as well as increasing self-confidence. The inhibiting factor is from the student himself, when the student's sport is complacent by playing or chatting with his friends, or difficult to line up. So the time for sports is very briefly used up to regulate students so that sports learning is not optimal. How to overcome it by making games for students. So, before they were in the line there was a game first whether it was a game related to the sports movement. The students were more interested in music or with the music movements that students had played upwards or did not want to leave the classroom because hearing music might be different as they left the page to follow sports learning. The supporting factors are in the form of an environment and a wide and adequate field. The inhibiting factors are from the students themselves, when they are playing for a while sometimes the students fall asleep playing or chatting with their friends. So the time for sports is very short-lived to regulate students so that sports learning is not optimal.

Students can have a character, meaning little by little the character can change for the better. I always encourage students in the sense that even the slightest progress I consider to be an achievement, the mistake I consider to be nonexistent. When students are wrong in doing sports movements I correct. As a teacher, don't ever assume that a mistake made by a student is a fatal mistake. When students make small mistakes don't be exaggerated. Good correction, 
give rewards, whether it's enthusiasm or praise for the progress of him. The goal is that the body is healthy, secondly to preserve culture, because the name of the traditional game is truly original culture from Indonesia.

For the psychic, I have also applied it to students in the form of knowledge, attitudes, characters, what can be done or not. The way is by giving guidance to students by telling the story first. When students look tired, I will give time for a short break. Then I will tell you about directions that can make them return to study well.

Religious, responsibility, social care, patriotism, hard work, discipline, honesty, democracy, curiosity. The constraints of students are not too many, there are only a few. For the application of the discipline itself, thank God has reached $80 \%$ to students. It is very important because in traditional games it contains the personality character of children, for example in the formation of existing religious characters so that in sports learning before the game takes place we must give greetings and so on, teach moral good or bad (behave well and politely), choose and channel children's creativity, giving children responsibility, teaching children about empathy, love and compassion, teaching the principle of good lead with understanding, teaching behavior about helping to help and care for others, teaching children to explore. I always get students to say hello when starting and ending sports learning. One of them should never be lazy when we are still given a complete, healthy body member so we must be grateful, we are still given time to exercise, there are still many people whose terms do not have time or do not have time to exercise, want to exercise but not biased. I always explain to children if they are given time to exercise do not use them for joking. I used to give sanctions in the form of reprimands. For example, if the student is not disciplined then I will instruct the student to move forward as if pinning the warming movement in front. Students are able to obey the rules with a sense of responsibility when doing sports rat mouse learning. Of course when the learning takes place students always help each other friends if their friends feel they don't understand. Of course they all always show their concern for their friends. The students I saw for SDN Periuk 2 in Tangerang City were very enthusiastic about their students. If there is one student who arrives late following sports learning, he will be given a non-severe sanction such as leading a warm up in front. But for students the sanctions have felt quite heavy, because the elementary students are still embarrassed to come forward to be sanctioned. If you make students discipline for school a little difficult because we have to really continue, must be really patient in educating students. Examples of small things from ourselves must be able to exemplify as well. In learning this time students play according to existing rules and students admit their own mistakes. In sports learning students do not differentiate between each other and are friendly towards their peers. Very enthusiastic because they rarely do these traditional games.

Basically, in sports activities with traditional games, mouse cats do not encounter obstacles because in the elementary school of Negeri Periuk 2, Tangerang City, which is the person in charge or sports teacher, is very capable in their fields so that they understand the steps of the game.

The following is a traditional way of playing mouse cats based on field observations in the preparation stage, all players pray before the game starts. Then later in the implementation phase all players do hompimpah, then two children at the end of the hompimpa do faint to become cats and mice. After completing the hompimpa or getting a player who plays a mouse and a cat all players join hands to make a cage (circle) except cats and mice.

Mice place themselves in the cage while the cat is outside, then at the third count, the cat starts looking for a strategy to catch mice by breaking into the cage. Mice try to avoid looking for a strategy so they don't get caught by cats and the cage players try to block the road so the 
cat can't enter the cage to catch mice. Instead the cage player frees the mouse to enter and leave the cage, the way the cage player keeps the mouse by squatting if the cat tries to pass under the arm and stand up if the cat tries to jump over the arm.

The game ends if the mouse has been caught and may switch players, players number 9 to 20 children. This game can be done by boys and girls the more players the more lively. From the results of the description of the observations and interviews above, the researcher found the character values that were internalized in the traditional mouse rat game, namely honest values, confidence values, and creative values.

\section{Discussion}

Based on the description of the above research in the cat mouse game integrated character values are religious values, curiosity values, honest values, values of responsibility, value of hard work, value of social care, democracy, discipline and love of the homeland. Regarding the values of characters integrated in cat mouse games, it should be understood that the development of individual characters includes four components, namely cognitive, affective, willingness and behavior. The cognitive component includes knowledge of good and bad, with a rational basis that will process creatively as a material for moral decisions. Furthermore, the stored knowledge will influence what values will be embedded in the affective component, to produce moral or ethical. These two components will then influence the component of willingness in the form of commitment to bring good and bad behavior. The basis of this commitment is based on knowledge to know the value of what is learned based on the knowledge that has been stored previously. The three components affect the last component, namely, overt behavior surfaces. Overt behavior has two aspects, namely personal virtues and social virtues, which include personal virtues are courage, discipline while social virtues are polite, trustworthy, have compassion for others (social care). If this continues to take place continuously, a habit that will become a permanent character will form. Based on the description above, it can be concluded that the traditional mouse mouse game is a play activity that does not use tools and involves many players, and can be done to fill empty time as a means of entertainment or to please the heart.

Based on the results of the research and discussion of the formulation of the problems described above, the researcher can conclude that in traditional games mouse cats internalized nine character values namely religious values, curiosity values, honest values, values of responsibility, value of hard work, value of social care, discipline, democracy and patriotism. The formation of a child's character can also be influenced by traditional regional games. Where child development can be considered by parents when children are playing. Children are trained to be able to accept defeat in games, learn honestly, obey rules, learn to work together in play groups, learn responsibility, and so on. To find out whether traditional games have an effect on the character building of children, the author conducted an interview with a teacher in the sports field at the Periuk 2 state elementary school in Tangerang City, according to the sports teacher at the school. their students' growth and development. 


\section{References}

[1] Dani wardani.: Bermain Sambil Belajar. Edukasia, Bandung (2009)

[2] Daryanto dan D. Suryati.: Implementasi Pendidikan Karakter di Sekolah. Gava Media., Yogyakarta (2013)

[3] Dharmamulya, Sukirman dkk.: Permainan Tradisional Purwangan.KEPEL PRESS, (2003)

[4] K. Euis.: Permainan Tradisional dan Perannya Dalam Mengembangkan Keterampilan Sosial Anak, (2007)

[5] M. Fatchul.: Pendidikan Karakter Konstruksi Teoritik dan Praktik. Ar-Ruzz Media, Yogyakarta (2011)

[6] A. Hermawan.: Pendidikan Budaya dan Karakter Bangsa. Nuansa Cendekia, (2014)

[7] G. Heri.: Pendidikan Karakter Konsep dan Implementasi. Alfabeta, Bandung: (2014)

[8] Helmawati.: Pendidikan Karakter Sehari-hari. PT Remaja Rosdakarya, Bandung (2017)

[9] Lusiana, Ernita.: MembangunPemahaman Karakter Kejujuran melalui Permainan Tradisional Jawa Pada Anak Usia Dini Di Kota Pati. Fakultas Ilmu Pendidikan. Universitas Negeri Semarang, Semarang: (2012)

[10] A.Majid, dan A. Dian.: Pendidikan Karakter Perspektif Islam. PT Remaja Rosdakarya, Bandung (2013)

[11] Mawardi.: Penelitian Tindakan Kelas. Bumi Aksara, Jakarta (2017)

[12] Mulyasa.: Start Manajemen Pendidikan Karakter. Bumi Aksara (2014)

[13] Misbach, Ifa H.: Peran Permainan Tradisional yang Bermuatan Edukatif Dalam Menyumbang Karakter dan Identitas Bangsa.Universitas Pendidikan Indonesia (2006)

[14] Sani, Ridwan Abdullah dan Muhammad Kadri.: Pendidikan Karakter Mengembangkan Karakter Anak yang Islami. Bumi Aksara, Jakarta (2016)

[15] Sugiyono.: Metode Penelitian Kualitatif, kualitatif dan R\&D. Alfabeta, Bandung: (2016)

[2] Taufik.: Pendidikan Karakter Berbasis Hadits. PT Rajagrafindo Persada, (2013) 